Katarzyna Białobrzeska

https://doi.org/10.26881/pwe.2018.43.09

ORCID: 0000-0003-4105-2475

Uniwersytet Warmińsko-Mazurski w Olsztynie

katarzyna.bialobrzeska@uwm.edu.pl

\title{
Przeciwdziałanie ubóstwu dzieci i młodzieży w Unii Europejskiej. Między planowaniem a dzialaniem
}

\section{Summary \\ Counteracting child and youth poverty in the European Union. Between planning and action}

The aim of the article is to examine whether the member states of the European Union guarantee children in poverty the right to specific means of equal opportunities as guaranteed by the European pillar of social rights. A strategy for counteracting poverty based on the A. Giddens's concept of the 'social investment state' was created in the EU. According to this concept, the state should support most of all these social groups which guarantee the highest social advantages. Following this idea, the union strategy for fighting poverty emphasizes the necessity of investing in children from early years of their lives. According to the social investment paradigm adopted by the European Commission, a crucial role in strategies for counteracting child poverty plays early childhood education and care.

Keywords: child poverty, counteract child poverty, investment in children, early childhood education and care

Słowa kluczowe: ubóstwo dzieci, przeciwdziałanie ubóstwu dzieci, inwestowanie w dzieci, wczesna opieka i edukacja

\section{Wprowadzenie}

Bieda towarzyszy ludzkości od zarania dziejów a walka z nią jest jedną z kluczowych aktywności podejmowanych zarówno w makro, mezo jak i mikroskali. Próby wyeliminowania, czy też znaczącego ograniczenia tego zjawiska w wymiarze globalnym nie przyniosły spektakularnych rezultatów, a świat, umownie i w dużym uproszczeniu, nadal możemy podzielić na bogatą północ i biedne południe. W dyskursie publicznym utarło się przekonanie, że problemy związane z niedostatkiem nie dotyczą krajów wysoko rozwiniętych, w tym bogatej Europy, a bieda jest stałą cechą krajów rozwijających się. Tymczasem ostatnie dekady obnażyły iluzoryczność i życzeniowość takiego toku myślenia o ubóstwie. W Europie narasta świadomość dotycząca pogłębiania się ubóstwa i to zarówno w kontekście globalnym, regionalnym, jak i jednostkowym. Przykładem reakcji na narastanie ubóstwa na starym kontynencie są inicjatywy i działania polityczne Unii 
Europejskiej na rzecz likwidacji biedy i wykluczenia społecznego w Europie. Działania te mogą być realizowane na mocy art. 136 i 137 traktatu amsterdamskiego z 1999 r. Traktat ten stał się przyczynił się do uznania walki z ubóstwem i wykluczeniem społecznym za jeden z głównych celów unijnej polityki społecznej.

W obrębie państw członkowskich Unii Europejskiej podjęto szereg działań zmierzających do realizacji założonych celów walki z biedą. Wypracowano wiele dokumentów strategicznych i instrumentów pozwalających osiągnąć ustalone założenia (Warzywoda-Kruszyńska 2012: 11-35).

Celem prezentowanego tekstu jest sprawdzenie, czy zgodnie z europejskim filarem praw socjalnych, dzieci, szczególnie te, które doświadczają ubóstwa, mają zagwarantowane prawo do szczególnych środków służących wyrównaniu szans. W treści artykułu skupiono się głównie na krytycznej analizie dyskursu z zakresu szeregu inicjatyw w Unii Europejskiej mających przeciwdziałać biedzie wśród dzieci. Starano się przedstawić i uzasadnić dysonans, jaki zachodzi między planowaniem a realizacją działań na rzecz zwalczania ubóstwa wśród najmłodszych w krajach unijnych.

\section{Konceptualizacja ubóstwa}

Ubóstwo, jak większość pojęć stosowanych w naukach społecznych, jest kategorią wieloznaczną, opisywaną, mierzoną i interpretowaną w obrębie danej dyscypliny naukowej. Interdyscyplinarny charakter tej kategorii pojęciowej wynika $\mathrm{z}$ faktu operowania przez różne nauki odrębnym aparatem pojęciowym i badawczym, nadającym interpretacjom ubóstwa swoisty rys. Współcześnie w interpretacjach ubóstwa odchodzi się od wąskiego ujęcia, dotyczącego głównie ekonomicznego ujmowania tego problemu, traktując je jako wielowymiarowy, złożony i dynamicznie zmieniający się zespół zjawisk. W dużym uproszczeniu można przyjąć definicję ubóstwa określającą je nie tylko jako brak wystarczających środków do życia, dochodu umożliwiającego zaspokojenie potrzeb bytowych jednostki czy rodziny, ale także jako współwystępowanie deficytów w innych obszarach życia ubogich, takich jak: edukacja, zdrowie, uczestnictwo w kulturze, w życiu społecznym i politycznym. Współcześni badacze zjawiska biedy koncentrują się nie tylko na biedzie materialnej, ale także na jej subiektywnym, relacyjnym i symbolicznym wymiarze. Taki wielowymiarowy sposób postrzegania ubóstwa został przyjęty w niniejszym opracowaniu jako pryzmat, przez który autorka dokonuje analizy kwestii związanych ze zjawiskiem ubóstwa wśród dzieci.

Koncepcją wartą przywołania jest koncepcja stworzona przez R. Lister (2007), która proponuje postrzeganie ubóstwa w kategoriach uwzględniających aspekty pozamaterialne biedy, podkreślając związek równorzędności i współzależności między materialnymi a relacyjno-symbolicznymi aspektami biedy. Zaproponowany przez nią schemat materialno-niematerialnego koła biedy jasno opisuje związki w nim zachodzące. W schemacie tym materialny rdzeń biedy stanowi środek koła - rdzeń określany mianem „niedającego się zaakceptować niedostatku”. Brzeg koła - obręcz przedstawia natomiast relacyjno-symboliczne 
aspekty biedy, których doświadczają ludzie żyjący w materialnym niedostatku. Zarówno brzeg koła, jak i jego środek są kształtowane przez relacje społeczne i kulturowe.

Analizując zjawisko biedy dziecięcej, szczególnego znaczenia nabiera troska o kompleksowe rozwiązania w ramach polityk społecznych, pozwalające przeciwdziałać ubóstwu materialnemu a także jego relacyjno-symbolicznym aspektom, które nierozerwalnie towarzyszą osobom żyjącym w niedostatku.

\section{Juwenizacja ubóstwa w Unii Europejskiej - paląca kwestia społeczna}

Ostatnie dwie dekady w polityce społecznej UE to okres formowania szeregu inicjatyw, które spowodowały nie tylko redefinicję samego pojęcia ubóstwa, ale także określiły na nowo jego przyczyny i skutki. W okresie tym nadano rangę narastającej kwestii ubóstwa w krajach unijnych, a co za tym idzie uznano konieczność wypracowania w politykach społecznych skutecznych instrumentów przeciwdziałania ubóstwu. W relatywnie bogatej wspólnocie państw wysokorozwiniętych uświadomiono sobie nie tylko skalę, dynamikę, ale i konsekwencje tego, narastającego problemu społecznego. Na potraktowanie ubóstwa w sposób priorytetowy wpłynęła dynamika narastania niedostatku w Europie wynikająca z głębokiego kryzysu ekonomicznego, którego skutki dotkliwie odczuły kraje UE, a także problemy związane z imigracją zalewającą kraje Europy zachodniej.

Za priorytetowe uznano działania mające przeciwdziałać ubóstwu wśród dzieci. Niedostatek w UE dotyka w największym zakresie dzieci i młodzież, co wydaje się być szczególnie zagrażające dla zrównoważonego rozwoju wspólnoty i poszczególnych państw narodowych. W obliczu danych obnażających narastające zjawisko biedy wśród najmłodszych mieszkańców Unii Europejskiej podjęto szereg inicjatyw w celu poprawy ich sytuacji. W polityce społecznej wspólnoty przyjęto i upowszechniono założenie, że „nierówności w dzieciństwie stanowią rzeczywiste zagrożenie dla akumulacji kapitału ludzkiego i przyczynę nierównych możliwości na rynku pracy i w późniejszym życiu” (Van Lancker 2013: 4). Przyjęto, że państwo powinno wprowadzić instrumenty, które zapewnią niwelowanie nierówności społecznych wśród dzieci i zapewnią im równy start. W interesie wspólnoty UE i poszczególnych państw leżeć powinna dbałość o rozwój najmłodszych, może ona bowiem zagwarantować w przyszłości dynamiczny rozwój i dobrobyt społeczeństw. Taki tok myślenia oparty jest na promowanej w Europie koncepcji „państwa społecznych inwestycji” (the social investment state) sformułowanej przez A. Giddensa w 1998 roku.

W rozumieniu A. Giddensa działalność państwa powinna być zbliżona do działalności przedsiębiorstwa, co oznacza, że państwo powinno dążyć do uzyskania maksymalnego zysku z poniesionych wydatków publicznych. Według tej koncepcji wsparcie państwa powinno dotyczyć przede wszystkim grup, które w największym stopniu gwarantują osiągnięcie społecznych korzyści. Dzieci stanowią najbardziej perspektywiczną z tego punktu widzenia grupę społeczną, a więc inwestowanie w tą grupę poprzez różne działania podejmowane przez władze państwowe powinny przyczynić się do wzrostu ich kapitału ludz- 
kiego. Inwestycje społeczne w najmłodszych, przede wszystkim pochodzących z rodzin ubogich, mają skutkować między innymi przerwaniem transmisji biedy w przyszłości.

Podążając za tym tokiem rozumowania, stworzono koncepcję zwalczania biedy kładącą szczególny nacisk na inwestowanie w dzieci od okresu wczesnego dzieciństwa, co miałoby zapobiec powstawaniu u nich deficytów rozwojowych. W 2002 r. państwa UE zadeklarowały realizację tzw. celów „barcelońskich”, czyli utworzenia do 2010 r. miejsc w instytucjach wczesnej edukacji i opieki dla 33\% dzieci w wieku do 3 lat oraz dla $90 \%$ dzieci w wieku przedszkolnym. W roku $2011 \mathrm{KE}$ wydała komunikat pt.: „Wczesna edukacja i opieka nad dzieckiem: gwarantujmy wszystkim dzieciom w UE dobry start w przyszłość". Opublikowany komunikat stał się dokumentem dyscyplinującym i ponaglającym państwa członkowskie do realizacji założonych celów „barcelońskich”. W dokumencie wyraźnie wskazuje się na konieczność zapewnienia wysokiej jakości usług edukacyjnych i opiekuńczych dla małych dzieci.

Od 2002 roku odnotować należy szereg inicjatyw wdrażających powyższe założenia w krajach unijnych. Ich poziom realizacji i dynamika w obrębie państw narodowych UE są zróżnicowane a wynika to z przyczyn natury ekonomicznej i społeczno-kulturowej.

Ważną inicjatywą Unii w kwestii dbałości o dobro dzieci stało się zalecenie Komisji Europejskiej z dnia 20 lutego 2013 r. pt.: „Inwestowanie w dzieci: przerwanie cyklu marginalizacji”, stanowiące wyodrębniony dokument w komunikacie Komisji Europejskiej „Inwestycje społeczne na rzecz wzrostu i spójności”. Komunikat KE zachęcał państwa członkowskie do reformy systemów zabezpieczenia społecznego z systemów reaktywnych na prewencyjne. Ta zmiana pozwoliłaby w przyszłości zapobiegać ryzykom społecznym na różnych etapach życia dzieci. Prewencja ubóstwa wśród dzieci a także rozwój wczesnej edukacji i opieki pozwoli realizować założenia rozwijania uczenia się przez całe życie, a przez to wpisze się w model polityki społecznej opartej na inwestycjach społecznych.

Komisja Europejska zaleciła państwom członkowskim dążącym do trwałego zwalczania biedy i wykluczenia społecznego dzieci oraz do podniesienia jakości ich życia, zastosowanie się do poniższych zasad:

1. Rozwiązywanie problemu ubóstwa i wykluczenia społecznego dzieci odbywać się powinno poprzez opracowanie przez państwa unijne zintegrowanych strategii, które poza kwestią ubóstwa materialnego kładą nacisk na promowanie równych szans. Strategie te powinny uwzględniać zasadę respektowania praw dziecka, w szczególności poprzez odwołanie się do postanowień Traktatu o Unii Europejskiej, Karty Praw Podstawowych Unii Europejskiej oraz do Konwencji o Prawach Dziecka Zgromadzenia Ogólnego ONZ.

2. Traktowanie dzieci w sposób podmiotowy, $\mathrm{z}$ dbałością o uwzględnianie interesu dziecka i respektowanie dziecięcych praw, z jednoczesnym uznaniem znaczenia wspierania rodzin jako kluczowego środowiska życia i rozwoju dzieci.

3. Stosowanie zrównoważonego podejścia zakładającego rozwój zarówno uniwersalnej polityki dążącej do promowania dobrostanu wszystkich dzieci, jak i podejścia ukierunkowanego na wspieranie dzieci znajdujących się w najbardziej niekorzystnej sytuacji. 
4. Koncentrowanie uwagi na dzieciach, które znajdują się w grupie ryzyka wykluczeniem społecznym i marginalizacją, a przede wszystkim na dzieciach romskich, dzieciach pochodzących z niektórych środowisk migrantów lub z niektórych mniejszości etnicznych, dzieciach specjalnej troski, w tym niepełnosprawnych, znajdujących się w pieczy zastępczej, dzieciach żyjących w środowisku ulicznym, a także tych, których rodzice odbywają karę więzienia, wychowujących się w gospodarstwach domowych samotnych rodziców lub dzieciach dorastających w rodzinie wielodzietnej.

5. Lobbowanie i wspieranie inwestycji w dzieci i rodziny, co zapewni ciągłość polityki i planowanie długoterminowe.

6. Ciągłe monitorowanie wpływu reform politycznych na położenie osób zagrożonych ubóstwem i marginalizacją oraz dążenie do łagodzenia niekorzystnych skutków tychże reform.

Zintegrowana strategia inwestowania w dzieci, zdaniem Komisji, powinna opierać się na trzech filarach: dostępie do odpowiednich zasobów, dostępie do usług wysokiej jakości po przystępnych cenach oraz prawie dzieci do partycypacji. W zakresie dostępu do odpowiednich zasobów zobligowano państwa członkowskie do szczególnej dbałości we wspieraniu aktywności zawodowej rodziców oraz łączenie świadczeń społecznych w sposób zabezpieczający przed naznaczaniem i stygmatyzowaniem.

W zakresie usług społecznych założono, że powinny one prowadzić do zmniejszenia nierówności wśród dzieci i zapewnić im równy start. Wytyczne te dotyczą nie tylko edukacji, lecz także dostępu do usług zdrowotnych i odpowiednich warunków mieszkaniowych. Wysoka jakość usług społecznych prowadzić ma do zwiększania umiejętności i kompetencji rodzicielskich, co ma zapobiec ustanowieniu pieczy zastępczej nad dziećmi i odbieraniu dzieci rodzicom z powodu biedy.

W zakresie praw dzieci do partycypacji Komisja Europejska zaleciła działania dwutorowe: zapewnienie wszystkim dzieciom, niezależnie od sytuacji materialnej, możliwości uczestnictwa w różnych formach spędzania czasu wolnego oraz prawo do wypowiadania się dzieci w kwestiach bezpośrednio je dotyczących, zarówno w kwestiach indywidualnych, jak i grupowych. Zaleca się zatem wszelkiego typu działania zwiększające podejście partnerskie do dzieci przez pracowników różnych służb społecznych.

Uczulono państwa członkowskie na kwestię przeciwdziałania biedzie wśród najmłodszych poprzez inwestowanie w dzieci od okresu wczesnego dzieciństwa. Przykładami mogą być poniższe inicjatywy:

- Wskazanie przez KE konieczności uznania przez państwa unijne problemu ubóstwa i wykluczenia społecznego dzieci za priorytetową kwestię w ramach Strategii Europa 2020. W zaleceniu przytoczono wytyczne i wskaźniki, na podstawie których monitorowane jest inwestowanie w dzieci w państwach członkowskich. W Eurostacie wyodrębniony został dział „Inwestowanie w dzieci” publikujący regularnie dane spływające $\mathrm{z}$ krajów unijnych. 
- Pisemna Deklaracja Parlamentu Europejskiego podpisana w roku 2015 o promowaniu inwestowania w dzieci (42/2015) będąca aktem wsparcia większości parlamentarzystów dla działań KE w kwestii zwalczania ubóstwa wśród dzieci.

- Realizacja przez Rad Europy od 2006 programu „Budowanie Europy dla dzieci i z dziećmi" (Building a Europe for and with Children), którego aktualizację stanowi Strategia na rzecz Praw Dziecka na lata 2016-2021.

\section{Przyczyny powodzeń i niepowodzeń we wdrażaniu strategii przeciwdzialania ubóstwu dzieci w Unii Europejskiej}

Opisane powyżej inicjatywy polityczne mimo wielu starań straciły swój impet i nie są w pełni realizowane. Powodów takiego rozwoju sytuacji jest wiele i choć cel podejmowanych inicjatyw jest szlachetny a kierunek działań słuszny, to na spowolnienie wdrażania zaleceń KE wpływ miały głównie czynniki pragmatyczne.

Nie bez znaczenia jest sytuacja ekonomiczna wspólnoty. Problemy finansowe przyczyniły się do wdrożenia polityki oszczędzania i skupienia się głównie na kwestiach gospodarczych i ekonomicznych a kwestia inwestowania w dzieci na podstawie prawa zwolniła tempo i powoli schodzi na plan dalszy.

Na plan pierwszy zaczęły wysuwać się inne palące kwestie a wśród nich problem bezrobocia młodych dorosłych, co z oczywistych względów wymagało interwencji i wypracowania rozwiązań systemowych. W drugiej dekadzie XXI wieku bardziej zagrożeni ubóstwem i wykluczeniem społecznym są młodzi dorośli niż dzieci i młodzież. Rozmiar biedy w najmłodszej kohorcie ludności krajów OECD ustabilizował się, zwiększył się natomiast wśród młodych dorosłych (Richardson 2014: 16).

Kolejnym problemem, który zdominował politykę społeczną krajów unijnych jest zalewająca kontynent imigracja. Do Europy wraz z falą uchodźców przybyła duża rzesza dzieci. W samym tylko 2015 roku do krajów UE dotarło blisko 364 tysiące dzieci z czego około $1 / 4$ bez opiekunów. W obliczu takich wyzwań kwestia ubóstwa i wykluczenia dzieci i młodzieży zmniejszyła swoją dynamikę.

Eurochild analizuje na bieżąco uwzględnianie zalecenia „Investing in Children” w europejskich semestrach i programach narodowych wynikających ze Strategii Europa 2020. Organizacja wskazuje, że państwa członkowskie nie zwracały należytej uwagi na inwestycje społeczne, w tym przede wszystkim na wspieranie dzieci i rodzin zagrożonych ekskluzją społeczną, także w wymiarze mieszkaniowym i zdrowotnym oraz na realizację ich prawa do partycypacji.

W założonym przez Komisję Europejską paradygmacie inwestycji społecznych w dzieci środkiem prowadzącym do tego celu ma być wczesna edukacja, czyli profesjonalne działania edukacyjno-opiekuńcze dla dzieci małych, do 3 roku życia, głównie tych, które pochodzą z rodzin biednych.

Wczesna edukacja ma doprowadzić do zmniejszenia nierówności społecznych poprzez promocję zatrudnienia matek, podnosząc nie tylko ich dochody, ale i ich kapitał 
ludzki i społeczny. Równocześnie wczesna edukacja ma zwiększyć szanse rozwoju dzieci z rodzin o niskim kapitale edukacyjnym i ekonomicznym. Warunkiem niezbędnym do realizacji podjętych założeń jest powszechny dostęp do tanich profesjonalnych instytucji wczesnej edukacji. Tymczasem analiza porównawcza 28 krajów Unii Europejskiej z punktu widzenia powszechności wczesnej edukacji i jej dostępności w zależności od statusu ekonomicznego oraz aktywności zawodowej matki ukazuje wiele barier w zrealizowaniu podjętych przez KE założeń.

Państwa europejskie jeszcze długo nie będą wstanie zagwarantować powszechnej wczesnej edukacji dla wszystkich dzieci w wieku do lat 3. Jest kilka grup państw, które na zróżnicowanym poziomie wypełniają zalecenia w tym zakresie. Nawet w Danii, państwie o najwyższym udziale dzieci we wczesnej edukacji - niespełna 90\% dzieci znajduje miejsce w tych instytucjach. Tylko w 6 państwach (Dania, Szwecja, Portugalia, Słowenia, Francja, Włochy) częściej niż co drugie małe dziecko chodzi do instytucji wczesnej edukacji. Przeciwwagę stanowi tu 6 państw postsocjalistycznych (Czechy, Słowacja, Polska, Rumunia, Węgry, Bułgaria), w których tylko od 3\% do 18\% małych dzieci korzysta z formalnych instytucji wychowawczo-opiekuńczych. (Van Lancker 2013: 19-21). Należy podkreślić, że dostęp do instytucji opiekuńczo-wychowawczych dla małych dzieci jest $\mathrm{w}$ wielu krajach zdominowany przez dzieci z rodzin lepiej sytuowanych. Tak jest w Polsce, Bułgarii, Rumunii, na Węgrzech oraz w Irlandii, Wielkiej Brytanii i w Grecji. Równocześnie, tylko w 6 krajach (Czechy, Słowacja, Austria, Litwa, Malta i Estonia) udział dziecka we wczesnej edukacji nie jest skorelowany ze statusem ekonomicznym rodziny.

W większości państw UE ani jakość, ani liczba miejsc w instytucjach wczesnej edukacji nie spełnia oczekiwań. Obecnie w UE żyje ponad $32 \mathrm{mln}$ dzieci poniżej wieku obowiązku szkolnego, lecz zaledwie około 15 mln korzysta z placówek wczesnej edukacji i opieki.

Na mapie pozytywnych przykładów zmian w kierunku przeciwdziałania ubóstwu wśród dzieci pojawia się wątek Polski. Z danych Eurostatu za lata 2016 i 2017 wynika, że w naszym kraju odnotowuje się niespotykaną od czasu wstąpienia do UE dynamika redukcji ubóstwa wśród dzieci. W 2016 r. w Polsce 24,2 proc. dzieci było zagrożonych ubóstwem lub wykluczeniem społecznym. W roku 2017 odsetek ten zmalał aż o 6,3 proc. do 17,9 proc. Zmiana wydaje się robić wrażenie, zważywszy na fakt, że w 2013 roku odsetek ubogich dzieci wynosił 29,8 proc. Polska w przeszłości w porównaniu z innymi krajami w niewielkim stopniu redukowała ubóstwo dzieci.

Zmniejszanie ubóstwa wśród rodzin z dziećmi to jeden z celów rządowego programu Rodzina 500+ realizowanego od ponad dwóch lat. Program ruszył w pierwszej połowie 2016 roku, co - zdaniem ekspertów - wpłynęło na spadek liczby dzieci zagrożonych ubóstwem lub wykluczeniem. Bezdyskusyjnie przyjąć należy, że program rządowy przyczynił się do redukcji ubóstwa w ujęciu absolutnym, w tym niemalże zlikwidował zawstydzające ubóstwo skrajne wśród najmłodszych Polaków. Rodzi się jednak pytanie o to, jakie działania zostaną podjęte w kierunku promowania wczesnej edukacji prowadzącej do zmniejszenia nierówności społecznych poprzez promocję zatrudnienia matek, podnosząc nie tylko ich dochody, ale i ich kapitał ludzki i społeczny. Z badań nad efektywnością 
programu Rodzina 500+ wynika, że bezrobocie wśród matek w naszym kraju wzrasta. Wczesna edukacja ma zwiększyć szanse rozwoju dzieci z rodzin o niskim kapitale edukacyjnym i ekonomicznym, a warunkiem niezbędnym do realizacji podjętych założeń jest powszechny dostęp do tanich profesjonalnych instytucji wczesnej edukacji.

\section{Podsumowanie}

Wczesne dzieciństwo i jego przebieg ma kluczowe znaczenie dla rozwoju podstawowych kompetencji i predyspozycji do uczenia się. Te z kolei w dużym stopniu wpływają na późniejszą ich edukację i osiągnięcia życiowe. Zgodnie z Europejskim filarem praw socjalnych dzieci, a w szczególności te ze środowisk znajdujących się w niekorzystnej sytuacji materialnej, powinny mieć prawo do szczególnych środków służących wyrównaniu szans.

Dzieci żyjące w rodzinach gorzej radzących sobie w kwestiach ekonomicznych powinny mieć prawo do wczesnej edukacji i opieki nad dzieckiem, które charakteryzują się dobrą jakością i przystępną ceną. Często jednak tak się nie dzieje. Wczesna edukacja i opieka nad dziećmi znacząco przyczynia się do rozwiązania problemu nierówności i wykluczenia społecznego, jednak nie zawsze jest ona realizowana na odpowiednim poziomie.

Opisane działania UE na rzecz zwalczania ubóstwa wśród dzieci w krajach wspólnoty przynoszą efekty, choć są one zróżnicowane dla poszczególnych członków Unii. W interesie wspólnoty UE i poszczególnych państw członkowskich powinna leżeć dbałość o rozwój dzieci, co w przyszłości może zagwarantować dynamiczny rozwój i dobrobyt społeczeństw. Promowanie w Europie koncepcji „państwa społecznych inwestycji” (the social investment state) sformułowanej przez A. Giddensa zapewne przyniesie w przyszłości wymierne efekty, pod warunkiem jednak, że ambitne plany zostaną zrealizowane. Według noblisty J. Heckmana inwestycje w kapitał ludzki najmłodszej generacji dają zwrot w wysokości co najmniej czterokrotnej, są opłacalne nie tylko dla dzieci, ale również dla całego społeczeństwa. Najwięcej korzyści, jak podkreśla J. Heckman, dają inwestycje w kapitał społeczny, jeśli są realizowane najwcześniej jak to tylko możliwe, tj. od 0 do 5 roku życia. Noblista dowodzi, że inwestycje te pozwalają na zredukowanie deficytu budżetowego i wzmocnienie gospodarki, a w dhuższym okresie przekładają się na lepsze zdrowie obywateli, zmniejszone zapotrzebowanie na usługi socjalne itd. (The Heckman Equation 2012: 1-2).

W sukcesywnym, systemowym działaniu na rzecz przeciwdziałania ubóstwu wśród dzieci zamieszkujących UE nieocenione wydają się być inicjatywy opisane w prezentowanym tekście, choć z oceną wyników ich wdrażania jest już nieco gorzej. Zadaniem Komisji Europejskiej jest wsparcie państw członkowskich w ich staraniach i działaniach na rzecz eliminowania ubóstwa, a głównym zadaniem komisji nie jest wywieranie presji na kraje członkowskie czy stosowanie przymusu, lecz motywowanie ich do ulepszenia dostępu do systemów wczesnej edukacji i opieki nad dzieckiem oraz podniesienia jakości tych systemów. I choć odpowiedzialność w tym obszarze spoczywa w głównej mierze na państwach członkowskich, to koordynacja tych działań przez KE, a co za tym idzie, ich monitorowanie i ocena stanowią silny stymulator $\mathrm{w}$ drodze do zmiany. 


\section{Literatura}

Giddens A. (1998), The Third Way. Cambridge, Polity.

Lister R. (2007), Bieda. Wydawnictwo Sic!

Richardson D. (2014), Child Poverty and Family Policies in the OECD. UNICEFF Office of Research. Florence, Innocenti.

The Heckman Equation (2012), Invest in early childhood development: Reduce deficits, strengthen the economy. heckmanequation.org/download.php?HeckmanDeficitPieceCUS, 19.05.2018.

Van Lancker W. (2013), Putting the child-centered investment strategy to the test, Evidence for EU27, „European Journal of Social Security”, 15.

Warzywoda-Kruszyńska W. (2012), Unia Europejska wobec biedy dzieci jakości ich życia. W: W. Warzywoda-Kruszyńska (red.), Bieda dzieci, zaniedbanie, wykluczenie społeczne. Łódź, Wydawnictwo Uniwersytetu Łódzkiego. 